\title{
Reclaiming Russian knapweed infested rangeland
}

\author{
LANI J. BENZ, K. GEORGE BECK, THOMAS D. WHITSON, AND DAVID W. KOCH
}

Authors are former graduate research assistant and associate professor, Department of Bioag Science and Pest Management, Colorado State University, Ft. Collins, Colo. 80523; professor and professor, Plant, Soil, and Insect Sciences, University of Wyoming, Laramie, Wyo. 82071 .

\section{Abstract}

Russian knapweed [Acroptilon repens (L.) DC.] is a creeping, perennial, unpalatable, noxious weed that infests thousands of rangeland and pasture hectares in the western U.S. often forming monocultures. Chemical or mechanical control of Russian knapweed usually is temporary allowing re-invasion of the weed over time. Our objective was to determine whether combining chemical or mechanical methods with seeding of perennial grasses would reclaim Russian knapweed infested areas more effectively than any of the treatments applied alone. Five suppression treatments combined with 5 seeded perennial grasses were evaluated to reclaim Russian knapweed infested site.

Two years after suppression treatments were done, clopyralid + 2,4-D + seeded grasses controlled 66 to $93 \%$ of Russian knapweed whereas clopyralid $+2,4-D$ applied alone controlled only $7 \%$ of Russian knapweed. Glyphosate + 'Critana' thickspike wheatgrass [Elymus lanceolatus (Scribn. \& Sm.) Gould] controlled 36\% of Russian knapweed 2 years after treatment (YAT) while glyphosate + 'Hycrest' crested wheatgrass [Agropyron cristatum (L.) Gaertn.], 'Bozoisky' Russian wildrye [Psathyrostachys juncea (Fisch.) Nevski], or 'Sodar' streambank wheatgrass [Elymus lanceolatus (Scribn. \& Sm.)] increased Russian knapweed growth 1.5, 2, and 1.6fold, respectively. Glyphosate applied alone tripled Russian knapweed growth. Metsulfuron + streambank wheatgrass controlled $61 \%$ of Russian knapweed 2 years after treatments were applied while metsulfuron applied alone controlled $40 \%$ of Russian knapweed. Mowing was ineffective and mowing + crested wheatgrass increased Russian knapweed growth about 2-fold. Clopyralid + 2,4-D + streambank wheatgrass yielded 6, 48, and 18 times more seeded grass than metsulfuron treated, mowed, or non-treated control plots seeded with streambank wheatgrass. Clopyralid + 2,4-D + streambank wheatgrass, while expensive $\left(\$ 262 \mathrm{ha}^{-1}\right)$, was the best treatment combination because it controlled Russian knapweed effectively while the sod-forming grass established well and helped to prevent re-invasion by the weed.

Key Words: rangeland weed control, IPM, integrated weed management, cultural control

Russian knapweed [Acroptilon repens (L.) DC] is a creeping, deep-rooted, aggressive, perennial weed considered nox-

\section{Resumen}

"Russian Knapweed" [Acroptilon repens (L.) DC.] es una maleza perenne, rastrera no apetecida por el ganado y tóxica que infesta miles de hectáreas de pastizales y praderas del oeste de U.S. y a menudo forma monocultivos. El control químico y mécanico de "Russian Knapweed" es temporal permitiendo con el tiempo la reinvasión de la maleza. Nuestro objetivo fue determinar si la combinación de métodos químicos y mecánicos con la siembra de zacates perennes sería mas efectiva para recuperar áreas infestadas de "Russian Knapweed" que con la aplicación individual de cualquiera de los tratamientos. Se evaluaron 5 tratamientos de supersión combinados con la siembra de 5 zacates perennes para recuperar un sitio infestado de "Russian Knapweed".

Dos años después de la aplicación de los tratamientos de supresión, el tratamiento de "Clopyralid" + "2,4-D" + siembra de zacates controló del 66 al $93 \%$ del "Russian Knapweed" mientras que "Clopyralid" + "2,4-D" solo controló el 7\% del "Russian Knapweed". Dos años después de aplicar el tratamiento (YAT) de "Glyphosate" + "Critana' "Thickspike wheatgrass" [Elymus lanceolatus (Scribn. \& Sm.) Gould] controlo $36 \%$ del "Russian Knapweed" en tanto "Glyphosate" + 'Hycrest' "crested wheatgrass" [Agropyron cristatum (L.) Gaertn.], 'Bozoisky' "Russian wildrye \{Psathyrostachys juncea (Fisch.) Nevski] o 'Sodar' "streambank wheatgrass" [Elymus lanceolatus (Scribn \& Sm.)] incrementaron el crecimiento del "Russian Knapweed" en 1.5, 2 y 1.6 veces respectivamante. El "Glyphosate" aplicado solo triplico el crecimiento del "Russian Knapweed". Dos años después de aplicado el "Metsulfuron" + "streambank wheatgrass" controló el $61 \%$ del "Russian Knapweed" en tanto que el "Metsulfuron" aplicado solo controló el $\mathbf{4 0 \%}$ del "Russian Knapweed". La siega fue inefectiva y la siega + "crested wheatgrass" incrementaron el crecimiento del "Russian Knapweed" en aproximadamente 2 veces. "Clopyralid" + "2,4-D" + "streambank wheatgrass" rindió 6,48 y 18 veces más del zacate sembrado que las parcelas tratadas con "Metsulfuron", segadas o no tratadas (control) y sembradas con "streambank wheatgrass". La combinación de "Clopyralid" + "2,4$\mathrm{D}^{\prime \prime}+$ "streambank wheatgrass", aunque cara $\left(\$ 262 \mathrm{ha}^{-1}\right)$, fue la mejor porque controló el "Russian Knapweed" efectivamente mientras los zacates formadores de césped se establecieron bien y ayudaron a prevenir la reinvasión de la maleza. 
ious in 21 of the United States (Maddox et al. 1985). It is invasive and can rapidly colonize an area due to its fast growth and extensive root system. It also exhibits allelopathic characteristics (Fletcher and Renney 1963, Watson and Renney 1974, Muir and Majak 1983, Stevens and Merrill 1985) and tends to form dense, monocultures (Watson 1980). Its bitter taste usually deters grazing livestock, however, fresh or dried Russian knapweed is toxic to horses, causing equine nigropallidal encephalomalacia, a fatal neurological disorder (Young et al. 1970).

Control of Russian knapweed typically has been by mechanical, chemical, or cultural means used alone. Control of Russian knapweed or other noxious weeds on rangeland is difficult because of vast area, uneven topography, and lower land value compared to cropland. Although chemical control of Russian knapweed is effective, it is costly, nontarget organisms must be considered, groundwater contamination must be avoided, and treated areas must be monitored and re-treated for weeds recurring from vegetative reproduction and viable seeds remaining in the soil. Russian knapweed often forms monocultures and successful chemical control may result in bare ground, which is as unproductive as the Russian knapweed infestations.

Plant competition can be used to complement other weed control methods (Bottoms et al. 1996). After several years, cereal crops planted in monoculture or crop/fallow rotation provided competition to control Russian knapweed (Watson 1980). Four years of winter rye (Secale cereale L.) or wheat (Triticum aestivum L.) monoculture decreased Russian knapweed populations 99 and $78 \%$ when crops were harvested for silage or grain, respectively (Sulima 1968). Russian knapweed is sensitive to light competition (Dall'Armellina and Zimdahl 1988). Flower production and root and shoot dry matter declined as light intensity was decreased while leaf area increased. Whitson et al. (1993) showed 'Ephraim' crested wheatgrass [Agropyron cristatum (L.) Gaertn.], 'Oahe' intermediate wheatgrass [Agropyron intermedium (Host.) Beauv.], and 'Bozoisky' Russian wildrye [Psathyrostachys juncea (Fisch.) Nevski] established in Russian knapweed stands without initial herbicide suppression at 20,45 , and $40 \%$ cover, 2 years after seeding. Perennial weed suppression is essential for successful grass establishment in integrated weed management. Unfortunately, little research has been conducted on integrated management of Russian knapweed. However, herbicide application followed by perennial grass seeding controlled 88 to $93 \%$ of leafy spurge (Euphorbia esula L.) 4 years after the combined treatments were invoked (Whitson et al. 1989). Seeding of competitive grasses in combination with herbicide and fertilizer treatments has been successful for long-term control of leafy spurge (Biesboer et al. 1993).

Herbicides chosen for Russian knapweed suppression on rangeland should include consideration of efficacy, residual activity, potential grass injury, sensitive habitat effects, and cost. Grasses chosen for long-term Russian knapweed management must exhibit adaptability to soil and climate, ease of establishment, competitiveness with weeds, palatability, nutritional value, good dry matter productivity, and stand longevity (Asay et al. 1991). The objective of this study was to determine whether combining suppression treatments with seeding of perennial grasses more effectively reclaimed Russian knapweed infested rangeland better than either method applied alone.

\section{Materials and Methods}

A field experiment was established in 1993 at Shoshoni, Wyo. on abandoned farm ground that was infested with Russian knapweed. The experiment was conducted for 3 years. The elevation was $1,469 \mathrm{~m}$ and the average annual precipitation was $22.5 \mathrm{~cm}$. The soil was a Tipperary-Trook loamy sand (mixed, mesic Typic Torripsaminents-coarseloamy, mixed mesic Typic Claciorthids) underlain by interbedded sandstone and varicolored shale of the Tertiary Wind River Formation; $89 \%$ sand, $4 \%$ silt, $7 \%$ clay with $1.1 \%$ organic matter and 8.0 $\mathrm{pH}$. The 5 by 5 factorial experiment was arranged in a split block design and treatment combinations were replicated 4 times. Main plots were 9 by $30 \mathrm{~m}$ and were methods used to suppress Russian knapweed. Suppression treatments included no treatment, mowing, clopyralid (3,6-dichloro-2-pyridinecarboxylic acid) + 2,4-D [(2,4-dichlorophenoxy)acetic acid], metsulfuron (methyl 2-[[[[(4methoxy-6-methyl-1,3,5-triazin-2yl)amino]carbonyl]amino]sulfonyl]benzoate), or glyphosate [N-(phosphonomethyl)glycine]. Clopyralid + 2,4-D $\left(0.3+1.7 \mathrm{~kg}\right.$ ai ha ${ }^{-1}$, sprayed at 225 liters $\mathrm{ha}^{-1}$ ) and metsulfuron (42 $\mathrm{g}$ ai ha ${ }^{-1}$ $+0.25 \% \mathrm{v} / \mathrm{v}$ non-ionic surfactant, sprayed at 225 liters ha $^{-1}$ ) were applied when Russian knapweed was in the late bloom stage on 9 July, 1993. Sequential treatments of glyphosate $\left(1.1 \mathrm{~kg}\right.$ ai ha ${ }^{-1}$ $+1.1 \mathrm{~kg} \mathrm{ha}^{-1}$, sprayed at 94 liters $\mathrm{ha}^{-1}$ ) were applied in the bud stage and again to remaining live plants on 11 June, 1993 and 7 August, 1993, respectively. All herbicides were sprayed with a $\mathrm{CO}_{2}$ pressurized backpack sprayer. Sequential mowings occurred in the bud stage on 15 June, 1993 and to regrowth on 18 August, 1993.

In November, 1993, main-plots were split into six, 9 by $6 \mathrm{~m}$ sub-plots. Each sub-plot was rototilled to a $15-\mathrm{cm}$ depth, then 1 perennial grass species was seeded with a rangeland drill. In addition to a non-seeded control treatment, 'Bozoisky' Russian wildrye grass, 'Hycrest' crested wheatgrass, 'Sodar' streambank wheatgrass, and 'Critana' thickspike wheatgrass were sown at 9, 11,11 , and $12 \mathrm{~kg}$ pure live seed $\mathrm{ha}^{-1}$, respectively. These grasses were chosen because of their positive characteristics relative to the objectives of this study. Crested wheatgrass is easy to establish, resistant to drought and cold, and is valued for its productivity and nutritional properties in early spring (Asay et al. 1991). Thickspike and streambank wheatgrasses are similar, native, perennial grasses that often have been used in disturbed site renovation (Anonymous 1984). They are drought resistant, establish easily because of robust seedling vigor, produce fine leaves, and form tight sod under dry rangeland conditions. Sod-forming grasses are good choices for revegetation when noxious weeds are a factor for site rehabilitation (Callihan and Evans 1991). Russian wildrye is drought resistant and the cultivar 'Bozoisky' has greater seedling vigor than other cultivars (Asay et al. 1991). Russian wildrye has dense basal leaves with high nutritive value. It is noted for early spring productivity and retains higher nutritive value during late summer and fall than many other grasses. 
Each of the 120 sub-plots representing an experimental unit was a combination of 1 suppression treatment and 1 seeded grass treatment. Treatments to suppress Russian knapweed and seeding of perennial grasses were done only during 1993 with no further management input. The outcome was evaluated in 1994 and 1995.

Data were collected twice during 1994 and 1995. Percent cover of each species was determined in late spring to measure the effectiveness of Russian knapweed suppression and seeded grass establishment. Canopy cover was determined by the Levy and Madden (1933) point method of pasture analysis. Biomass of each species was determined in late summer.

Baseline data were collected 8-10 June 1993 and used as a basis to monitor changes resulting from the various management systems. Data were collected in the same locations in each plot at about the same time in 1993, 1994, and 1995, after all vegetation had emerged and Russian knapweed was in the vegetative to early bud growth stage. Biomass was harvested in August, 1994 and 1995. Above ground vegetation was removed by clipping four, $0.25 \mathrm{~m}^{2}$ quadrats in each sub-plot, taking care not to harvest along permanent transects. Clippings were separated by species and oven-dried at $35^{\circ} \mathrm{C}$ for 48 hours to a constant weight.

Analysis of variance (ANOVA) was used to compare 2 main effects: suppression treatments as main plots, seeded perennial grasses as the split plot, and subsequent interactions. Percent cover data were arcsine square root transformed and all weight measurements were cube root transformed to stabilize variance; however, original values are reported. Residual plots of transformed data indicated no violations of the assumptions associated with ANOVA. Means for suppression treatments, seeded grass species, and interactions were separated using Fisher's protected least significant difference (LSD; $\alpha=0.05$ ). The expense ha $^{-1}$ of each treatment combination was calculated and compared. Only costs of herbicides or mowing plus grass seed were used because application and seeding costs vary substantially.

Data from 1994 and 1995 were analyzed separately because of varying climatic conditions at the site. Vegetation varied substantially from year to year because 1994 was the worst drought in recorded history while 1995 was the second highest precipitation on record.

\section{Results and Discussion}

Russian knapweed baseline cover ranged from 37 to $40 \%$ and did not differ among suppression treatments before they were applied (data not shown, Benz 1997). In 1994, all herbicides controlled Russian knapweed better than mowing or the non-treated control (Table 1). Russian knapweed emerged earlier in mowed plots than in all plots treated with a herbicide or in non-treated control plots (data not shown, Benz 1997). Mowing may have altered shoot apical dominance causing more rapid emergence the following spring. Russian knapweed was suppressed best by clopyralid + 2,4-D (98\% decrease in cover) and metsulfuron (99\% decrease in cover). Plots treated with clopyralid + 2,4-D or metsulfuron in 1993 yielded about $75 \%$ less Russian knapweed in 1994 than glyphosate treated plots and $85 \%$ less than in mowed or non-treated control plots (Table 1). Under average weather conditions, the best opportunity for grasses to establish the year following seeding would occur where Russian knapweed was adequately controlled. Drought in 1994 interfered with grass establishment in all plots. Weather conditions will influence grass establishment even where noxious weeds are controlled adequately. For example, a second experiment was conducted simultaneously near Mead, Colo. and although Russian knapweed was controlled with clopyralid + 2,4-D and metsulfuron similarly to that observed at the Wyo. site, seedling wheatgrasses were killed in 2 of 4 replications because of cold temperatures. Killed grass seedlings were in replications located in the bottom of a draw and had emerged in late winter

Table 1. Russian knapweed cover and biomass in 1994 as influenced by suppression treatments averaged over all seeded grasses.

\begin{tabular}{lccc}
\hline \hline Treatment & Rate & \multicolumn{2}{c}{ Russian knapweed } \\
\hline & $\left(\mathrm{kg} \mathrm{ha}^{-1}\right)$ & $(\% \text { cover })^{1}$ & $\left(\mathrm{~kg} \mathrm{ha}^{-1}\right)^{1}$ \\
Clopyralid & 0.3 & $0.7 \mathrm{c}$ & $20 \mathrm{c}$ \\
$+2,4-D$ & +1.7 & & $72 \mathrm{~b}$ \\
Glyphosate & 1.1 & $4 \mathrm{~b}$ & $16 \mathrm{c}$ \\
$(6-93+8-93)$ & +1.1 & $0.2 \mathrm{c}$ & $117 \mathrm{a}$ \\
Metsulfuron & 0.042 & $43 \mathrm{a}$ & $117 \mathrm{a}$ \\
Mowing & 0 & & \\
$(6-93+8-93)$ & 0 & $43 \mathrm{a}$ & \\
Control & 0 & &
\end{tabular}

Cover data were analyzed as arcsine square root transformations and biomass analyzed as cube root transformations, but are presented as original values. Means followed by the same letter do not differ, LSD (P>0.05).

${ }^{2}$ Non-ionic surfactant added at $0.25 \% \mathrm{v} / \mathrm{v}$ apparently because of better soil moisture conditions than the 2 replications located on a ridge top where grasses had not yet emerged. Seedling grasses in the draw did not survive $-20^{\circ} \mathrm{C}$ temperatures.

When weather conditions inhibit grass establishment, surviving seed will emerge later after conditions become suitable for germination. The best opportunity for grass establishment over time in Russian knapweed infested sites would occur where weeds are controlled adequately for the longest period. In 1995, 2 years after treatment (YAT), there was 13 times more Russian knapweed cover in glyphosate treated, mowed, and non-treated control plots than in clopyralid $+2,4-\mathrm{D}$ plots $(4 \%)$ and nearly 3 times more than in metsulfuron treated plots $(18 \%$; data not shown, Benz 1997). Long term control from clopyralid + 2,4-D (92\% decrease in cover) was evident 2 years after treatment while glyphosate showed none. Metsulfuron decreased cover of Russian knapweed by $99 \%$ after 1 year but only by $65 \%$ after 2 years.

Russian knapweed growth in 1995 was influenced by the interaction of the suppression treatments and the seeded grass species. Any grass species seeded after Russian knapweed was suppressed with clopyralid $+2,4-\mathrm{D}$, produced 66 to 93\% less Russian knapweed biomass than when no grass was sown (Table 2). Clopyralid $+2,4$-D plus any seeded perennial grass were the only combinations to produce less Russian knapweed consistently compared to plots seeded with grass but without suppression. Metsulfuron combined with streambank wheatgrass produced the least Russian knapweed $\left(274 \mathrm{~kg} \mathrm{ha}^{-1}\right)$. Among plots sprayed with metsulfuron, those seeded with streambank wheatgrass or Russian 
Table 2. The influence of suppression treatments interacting with seeded grasses on Russian knapweed biomass production in 1995 .

\begin{tabular}{|c|c|c|c|c|c|c|}
\hline \multirow[b]{2}{*}{ Treatment } & \multirow[b]{2}{*}{ Rate } & \multicolumn{5}{|c|}{ Russian knapweed biomass } \\
\hline & & $\begin{array}{l}\text { Crested } \\
\text { wheatgrass }\end{array}$ & $\begin{array}{c}\text { Russian } \\
\text { wildrye }\end{array}$ & $\begin{array}{l}\text { Streambank } \\
\text { wheatgrass }\end{array}$ & $\begin{array}{l}\text { Thickspike } \\
\text { wheatgrass }\end{array}$ & $\begin{array}{l}\text { No grass } \\
\text { control }\end{array}$ \\
\hline & $\left(\mathrm{kg} \mathrm{ha}^{-1}\right)$ & ---------- & - n & $\left.\mathrm{ha}^{-1}\right)^{1}-$ & --. & ----- \\
\hline $\begin{array}{l}\text { Clopyralid } \\
+2,4-D\end{array}$ & $\begin{array}{r}0.3 \\
+1.7\end{array}$ & $83 \mathrm{C} \mathrm{c}$ & $152 \mathrm{C} \mathrm{d}$ & $43 \mathrm{D} \mathrm{c}$ & $193 \mathrm{~B} \mathrm{c}$ & $567 \mathrm{~A} \mathrm{~b}$ \\
\hline $\begin{array}{l}\text { Glyphosate } \\
(6-93+8-93)\end{array}$ & $\begin{array}{r}1.1 \\
+1.1\end{array}$ & $896 \mathrm{C}$ ab & $1546 \mathrm{AB}$ a & $1149 \mathrm{BC}$ a & $362 \mathrm{D} \mathrm{b}$ & $1836 \mathrm{~A} \mathrm{a}$ \\
\hline Metsulfuron $^{2}$ & 0.042 & $523 \mathrm{~A} \mathrm{~b}$ & $523 \mathrm{~A} \mathrm{c}$ & $274 \mathrm{C} \mathrm{b}$ & $373 \mathrm{~B}$ ab & $371 \mathrm{~B} \mathrm{c}$ \\
\hline $\begin{array}{l}\text { Mowing } \\
(6-93+8-93)\end{array}$ & $\begin{array}{l}0 \\
0\end{array}$ & $1120 \mathrm{~A} \mathrm{a}$ & $1112 \mathrm{~A} \mathrm{ab}$ & $1047 \mathrm{~A} \mathrm{a}$ & $809 \mathrm{~A} \mathrm{a}$ & $896 \mathrm{~A} \mathrm{ab}$ \\
\hline Control & 0 & $586 \mathrm{AB} \mathrm{b}$ & $718 \mathrm{~A} \mathrm{~b}$ & $700 \mathrm{AB}$ a & $564 \mathrm{~B}$ ab & $609 \mathrm{AB} b$ \\
\hline
\end{tabular}

${ }^{1}$ Data were analyzed as cube root transformations but are presented as original values. Use upper case letters to compare means within a row and lower case letters to compare means within a column. Means followed by the same letter do not differ, LSD ( $\mathrm{P}>0.05)$.

${ }^{2}$ Non-ionic surfactant added at $0.25 \% \mathrm{v} / \mathrm{v}$

wildrye produced 28 and $61 \%$ less Russian knapweed biomass than plots seeded with these grasses but without suppression treatments. Over 5 times more Russian knapweed was harvested from glyphosate-only treated plots $\left(1,836 \mathrm{~kg} \mathrm{ha}^{-1}\right)$ than from plots where glyphosate was combined with thickspike wheatgrass (362 $\left.\mathrm{kg} \mathrm{ha}^{-1}\right)$. Glyphosate provided no advantage over mowing except in thickspike wheatgrass plots where half as much Russian knapweed was harvested than in mowed plots (362 vs $\left.809 \mathrm{~kg} \mathrm{ha}^{-1}\right)$. The characteristics of thickspike wheatgrass as a revegetation species may have enhanced this combination. It forms tight sod under dry rangeland conditions, has robust seedling strength, and performs well in low fertility or eroded sites (Asay et al. 1991). Mowing was a poor suppression treatment and did not control Russian knapweed effectively in any year. In all plots seeded with perennial grasses where mowing was the suppression treatment, 4 to 24 times more Russian knapweed was harvested than in these same grass plots where clopyralid + 2,4-D was used. Russian knapweed shoot apical dominance could have changed because of mowing, which may have caused more shoots per unit area and decreased the opportunity for seeded grasses to establish. In plots where little Russian knapweed biomass was harvested, the suppression treatment was effective enough to allow successful establishment and growth of seeded grass, which kept Russian knapweed from re-invading.
Our results indicate that glyphosate should be re-applied the year following the first treatment, metsulfuron may need to be re-applied 2 years after the first treatment, and clopyralid + 2,4-D may provide sufficient suppression so re-application would not be necessary.

Seeded grass cover in 1994 was less than 3\% for all species. Poor germination and establishment was influenced by severe drought in 1994. Seeded grasses were established, however, by the time cover data were collected in spring, 1995. Herbicides suppressed Russian knapweed better in 1994 than mowing or no treatment. Herbicides helped seeded grass establish by suppressing Russian knapweed and decreasing its competition with seeded grasses. A suppression treatment by seeded grass

species interaction effect in 1994 and 1995 showed that herbicides aided seeded grass establishment better than mowing. In 1994 for example, crested wheatgrass cover in plots treated with clopyralid + 2,4-D, glyphosate, or metsulfuron ranged from 4 to $6 \%$ and crested wheatgrass cover in these plots was 15 times greater than in mowed and nontreated control plots seeded with this grass (data not shown, Benz 1997). In 1995, all plots where Russian knapweed was suppressed with a herbicide and then seeded with a perennial grass, had 3 to 18 times greater seeded grass cover than mowed or non-treated control plots that were seeded with a perennial grass except where glyphosate was combined with Russian wildrye (Table 3). For example, grass cover in metsulfuron treated plots seeded with crested wheatgrass $(57 \%)$ was nearly 4 times more than grass cover in plots seeded with crested wheatgrass that did not receive a suppression treatment $(15 \%)$ and over 8 times more grass cover than in mowed plots seeded with crested wheatgrass $(7 \%)$.

In 1995, seeded grass biomass was influenced by suppression treatments interacting with seeded grass species. In general, plots where Russian knapweed was suppressed with a herbicide and then seeded with crested wheatgrass had more grass biomass in 1995 than where other perennial grasses were sown. In plots treated with glyphosate or metsulfuron, crested wheatgrass biomass was 3 to 20 times and 15 to 100 times greater, respectively, than where other grasses were sown (Table 4). This effect most

Table 3. The influence of suppression treatments interacting with seeded grasses on seeded grass cover in 1995.

\begin{tabular}{|c|c|c|c|c|c|c|}
\hline \multirow[b]{2}{*}{ Treatment } & \multirow[b]{2}{*}{ Rate } & \multicolumn{4}{|c|}{ Seeded grass cover } & \multirow[b]{2}{*}{$\begin{array}{l}\text { No grass } \\
\text { control }\end{array}$} \\
\hline & & $\begin{array}{l}\text { Crested } \\
\text { wheatgrass }\end{array}$ & $\begin{array}{l}\text { Russian } \\
\text { wildrye }\end{array}$ & $\begin{array}{l}\text { Streambank } \\
\text { wheatgrass }\end{array}$ & $\begin{array}{l}\text { Thickspike } \\
\text { wheatgrass }\end{array}$ & \\
\hline & $\left.\mathrm{ha}^{-1}\right)$ & - & - & $(\%)^{1}-$ & & \\
\hline $\begin{array}{l}\text { Clopyralid } \\
+2,4-\mathrm{D}\end{array}$ & $\begin{array}{r}0.3 \\
+1.7\end{array}$ & $55 \mathrm{~A} \mathrm{ab}$ & $5 \mathrm{C} \mathrm{a}$ & $15 \mathrm{~B} \mathrm{a}$ & $18 \mathrm{~B}$ a & $0 \mathrm{D} \mathrm{a}$ \\
\hline $\begin{array}{l}\text { Glyphosate } \\
(6-93+8-93)\end{array}$ & $\begin{array}{r}1.1 \\
+1.1\end{array}$ & $46 \mathrm{~A} \mathrm{~b}$ & $3 \mathrm{C} \mathrm{ab}$ & $18 \mathrm{~B}$ a & $11 \mathrm{~B} \mathrm{~b}$ & $0 \mathrm{D} \mathrm{a}$ \\
\hline Metsulfuron $^{2}$ & 0.042 & $57 \mathrm{~A} \mathrm{a}$ & $5 \mathrm{C} \mathrm{a}$ & $11 \mathrm{~B} \mathrm{a}$ & $10 \mathrm{~B} \mathrm{~b}$ & $0 \mathrm{D} \mathrm{a}$ \\
\hline $\begin{array}{l}\text { Mowing } \\
(6-93+8-93)\end{array}$ & $\begin{array}{l}0 \\
0\end{array}$ & $7 \mathrm{~A} \mathrm{~d}$ & $0 \mathrm{~B} \mathrm{c}$ & $1 \mathrm{~B} \mathrm{~b}$ & $1 \mathrm{~B} \mathrm{c}$ & $0 \mathrm{~B} \mathrm{a}$ \\
\hline Control & 0 & $15 \mathrm{~A} \mathrm{c}$ & $1 \mathrm{~B} \mathrm{bc}$ & $2 \mathrm{~B} \mathrm{~b}$ & $1 \mathrm{~B} \mathrm{c}$ & $0 \mathrm{C} \mathrm{a}$ \\
\hline
\end{tabular}

${ }^{\mathrm{D}}$ Data were analyzed as arcsine square root transformations but are presented as original values. Use upper case letters to compare means within a row and lower case letters to compare means within a column. Means followed by the same letter do not differ, LSD ( $\mathrm{P}>0.05)$.

${ }^{2}$ Non-ionic surfactant added at $0.25 \% \mathrm{v} / \mathrm{v}$ 
Table 4. The influence of suppression treatments interacting with seeded grasses on harvested seeded grass biomass in 1995.

\begin{tabular}{|c|c|c|c|c|c|c|}
\hline \multirow[b]{2}{*}{ Treatment } & \multirow[b]{2}{*}{ Rate } & \multicolumn{4}{|c|}{ Harvested grass biomass } & \multirow[b]{2}{*}{$\begin{array}{l}\text { No grass } \\
\text { control }\end{array}$} \\
\hline & & $\begin{array}{l}\text { Crested } \\
\text { wheatgrass }\end{array}$ & $\begin{array}{c}\text { Russian } \\
\text { wildrye }\end{array}$ & $\begin{array}{l}\text { Streambank } \\
\text { wheatgrass }\end{array}$ & $\begin{array}{l}\text { Thickspike } \\
\text { wheatgrass }\end{array}$ & \\
\hline & $\left(\mathrm{kg} \mathrm{ha}^{-1}\right)$ & - n & - & $\left.\mathrm{ha}^{-1}\right)^{1}$ & & 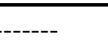 \\
\hline $\begin{array}{l}\text { Clopyralid } \\
+2,4-\mathrm{D}\end{array}$ & $\begin{array}{r}0.3 \\
+1.7\end{array}$ & $335 \mathrm{~A} \mathrm{~b}$ & $3 \mathrm{C} \mathrm{a}$ & $242 \mathrm{AB}$ a & $78 \mathrm{~B}$ ab & $0 \mathrm{C} \mathrm{a}$ \\
\hline $\begin{array}{l}\text { Glyphosate } \\
(6-93+8-93)\end{array}$ & $\begin{array}{r}1.1 \\
+1.1\end{array}$ & $454 \mathrm{~A} \mathrm{~b}$ & $21 \mathrm{Ca}$ & $69 \mathrm{~B} \mathrm{ab}$ & $159 \mathrm{~B}$ a & $0 \mathrm{C} \mathrm{a}$ \\
\hline Metsulfuron $^{2}$ & 0.042 & $634 \mathrm{~A} \mathrm{a}$ & $6 \mathrm{~B} \mathrm{a}$ & $40 \mathrm{~B} \mathrm{bc}$ & $36 \mathrm{~B} \mathrm{bc}$ & $0 \mathrm{C} \mathrm{a}$ \\
\hline $\begin{array}{l}\text { Mowing } \\
(6-93+8-93)\end{array}$ & $\begin{array}{l}0 \\
0\end{array}$ & $18 \mathrm{~A} \mathrm{c}$ & $6 \mathrm{~A} \mathrm{a}$ & $5 \mathrm{Ad}$ & $6 \mathrm{~A} \mathrm{c}$ & $0 \mathrm{~A}$ a \\
\hline Control & 0 & $44 \mathrm{~A} \mathrm{c}$ & $0 \mathrm{~B} \mathrm{a}$ & $13 \mathrm{AB} \mathrm{cd}$ & $8 \mathrm{AB} \mathrm{c}$ & $0 \mathrm{~B} \mathrm{a}$ \\
\hline
\end{tabular}

${ }^{\mathrm{T}}$ Data were analyzed as cube root transformations but are presented as original values. Use upper case letters to compare means within a row and lower case letters to compare means within a column. Means followed by the same letter do not differ, LSD $(\mathrm{P}>0.05)$.

${ }^{2}$ Non-ionic surfactant added at $0.25 \% \mathrm{v} / \mathrm{v}$

likely was caused by drought in 1994 when crested wheatgrass was the only perennial grass to grow in the dry environment. In plots where Russian knapweed was suppressed with clopyralid + $2,4-\mathrm{D}$ and then seeded with crested wheatgrass, 100 times more grass biomass $\left(335 \mathrm{~kg} \mathrm{ha}^{-1}\right)$ was produced than in plots seeded with Russian wildrye $(3 \mathrm{~kg}$ $\mathrm{ha}^{-1}$ ), and 4 times more than those seeded with thickspike wheatgrass $\left(78 \mathrm{~kg} \mathrm{ha}^{-1}\right)$. Plots treated with clopyralid $+2,4$-D then seeded with crested wheatgrass or streambank wheatgrass had similar yields in 1995 . The clopyralid $+2,4-\mathrm{D}$ plus streambank wheatgrass combination had less Russian knapweed than all other plots treated with clopyralid $+2,4-$ D or seeded with streambank wheatgrass. The long term Russian knapweed control provided by clopyralid $+2,4-D$ allowed vigorous seeded grass growth among the wheatgrasses in 1995 . The similar yields between crested wheatgrass and streambank wheatgrass in plots treated with clopyralid + 2,4-D may have been at least partially caused by minor injury to crested wheatgrass from the herbicide. The clopyralid + 2,4-D label states that crested wheatgrass may be injured under drought conditions. The similarity between crested wheatgrass and streambank wheatgrass yields in plots treated with clopyralid + 2,4-D is in sharp contrast to those plots treated with glyphosate or metsulfuron. It is clear that plots originally treated with glyphosate or metsulfuron needed retreatment in 1995 whereas those treated with clopyralid + 2,4-D may not have needed retreatment until 1996, if at all. Effective, long term control of weeds, especially perennial, noxious weeds, is an important consideration when designing integrated weed management systems for rangelands.

Plots treated with glyphosate yielded 4 times more thickspike wheatgrass biomass $\left(159 \mathrm{~kg} \mathrm{ha}^{-1}\right)$ than those treated with metsulfuron $\left(36 \mathrm{~kg} \mathrm{ha}^{-1}\right)$ and 28 times more than mowed plots $\left(6 \mathrm{~kg} \mathrm{ha}^{-1}\right)$. Also, suppression treatments that controlled Russian knapweed best did not necessarily provide the most seeded grass production. Metsulfuron treated plots produced about twice as much crested wheatgrass biomass $\left(634 \mathrm{~kg} \mathrm{~h}^{-1}\right)$ than those treated with clopyralid +2,4-D $\left(335 \mathrm{~kg} \mathrm{ha}^{-1}\right)$ and 14 times more than in the non-treated control plots $\left(44 \mathrm{~kg} \mathrm{ha}^{-1}\right)$, although over 6 times more Russian knapweed bio-

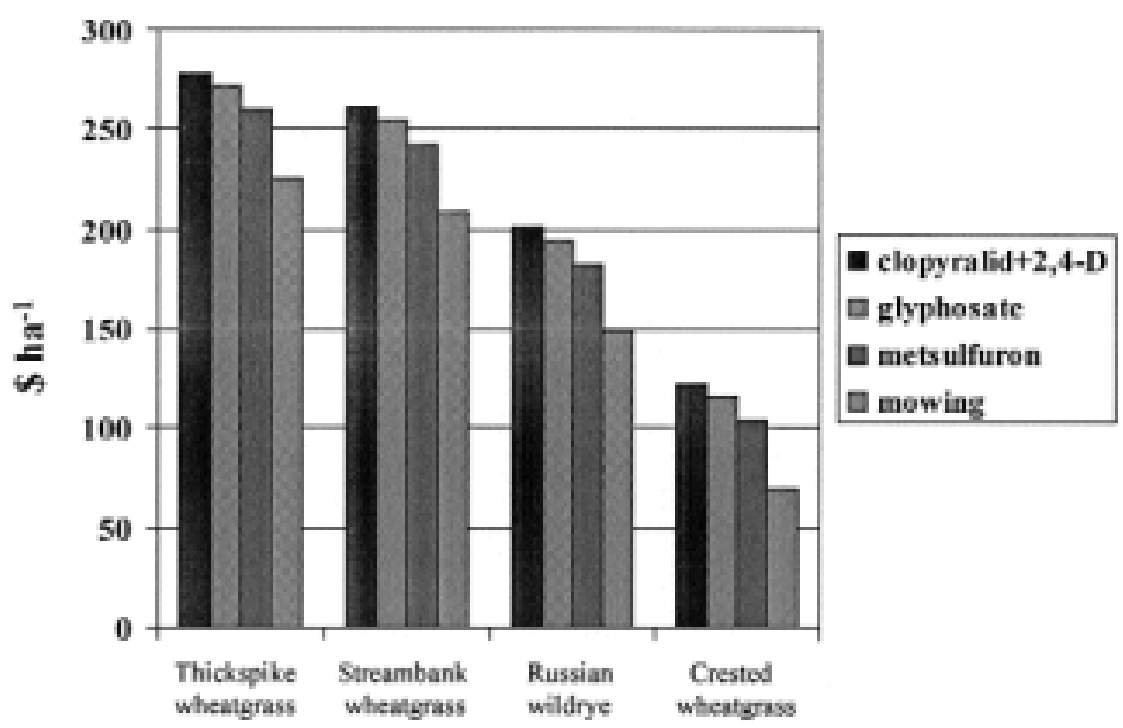

Fig.1. Cost comparison of the suppression treatments combined with seeded grasses. Only the cost of herbicides or mowing plus grass seed were used. mass was harvested from metsulfuron plus crested wheatgrass plots than from clopyralid + 2,4-D plus crested wheatgrass plots. Again, this effect may be a reflection of minor crested wheatgrass injury from clopyralid $+2,4-\mathrm{D}$ caused under drought. Bozoisky Russian wildrye did not establish well at this site, however it was successful in other Wyoming revegetation studies (Ferrell et al. 1992).

The most expensive treatment combination was clopyralid $+2,4$-D plus thickspike wheatgrass (\$278/ha) and the least expensive was mowing plus crested wheatgrass $\left(\$ 70\right.$ ha $^{-1}$; Fig. 1$)$. The combination of metsulfuron plus crested wheatgrass resulted in the greatest grass biomass per dollar invested in the management system, but it left as much Russian knapweed in the plot area as the no suppression plus crested wheatgrass combination 2 years after treatment. Glyphosate plus crested wheatgrass caused a similar result. Clopyralid + 2,4-D was the most expensive suppression treatment $\left(\$ 67 \mathrm{ha}^{-1}\right)$, but controlled the most Russian knapweed for the longest period of time and retreatment may not have been necessary. Plots treated with glyphosate $\left(\$ 61 \mathrm{ha}^{-1}\right)$ or metsulfuron $\left(\$ 49 \mathrm{ha}^{-1}\right)$ would have to be retreated thus adding to the expense of those treatment combinations. Glyphosate would be a poor choice for retreatment after grass establishment because it is non-selective. Our study indicates that clopyralid $+2,4-D$ plus streambank 
wheatgrass, while expensive (\$262 $\left.\mathrm{ha}^{-1}\right)$, provided the best long-term Russian knapweed control and good grass establishment, although grass establishment was not better than clopyralid + 2,4-D plus crested wheatgrass. Crested wheatgrass is a bunchgrass and most productive early in the growing season. Streambank wheatgrass is a sod-forming species that retains its productivity and nutritive value later in the growing season than crested wheatgrass. Sod-forming grasses are considered good choices as part of a long-term noxious weed management system. The best treatment combination resulting from our study was clopyralid + 2,4-D plus streambank wheatgrass and would be particularly well suited to areas where only native grasses are desired. Given the ease of establishment of crested wheatgrass, especially under drought conditions that are common in the Intermountain West, a sound recommendation to reclaim Russian knapweed infested rangeland or pastures would be clopyralid + 2,4-D plus streambank wheatgrass plus crested wheatgrass. Both grass species would establish easily and crested wheatgrass would provide early season grazing opportunities and competition with Russian knapweed that was recovering from suppression, whereas sod-forming streambank wheatgrass would provide long-term competition with Russian knapweed to prevent its re-invasion and provide grazing later into the season.

Previous studies (Christianson et al. 1994, Ferrell et al. 1995, Whitson et al. 1989) showed that integration of treatments is more effective than using single weed control techniques for perennial weeds. Our data support the hypothesis that a combination of a suppression treatment plus a seeded perennial grass was more effective than either method alone to reclaim Russian knapweed infested rangeland. The grasses used in our research needed initial suppression of Russian knapweed to permit establishment, and herbicides worked better than mowing.

\section{Literature Cited}

Anonymous. 1984. Critana thickspike wheatgrass: A conservation plant for Montana and Wyoming. USDA Soil Conser. Service, Plant Materials Center, Bridger, Mont. 59014.
Asay, K.H., M.D. Rumbaugh, and T.A. Jones. 1991. Improved grasses and forbs for intermountain rangelands. p. 138-152 In: Noxious Range Weeds. L.F. James, J.O. Evans, M.H. Ralphs, and R.D. Child, (eds.), Westview Press, Boulder, Colo.

Benz, L.J. 1997. The feasibility of developing integrated management systems to reclaim Russian knapweed infested rangeland for multiple use. M.S. Thesis, Colorado State Univ., Ft. Collins, Colo.

Biesboer, D.D., W.L. Koukkari, and B. Darveaux. 1993. Controlling leafy spurge in Minnesota with competitive species and combined management practices. Proc. Great Plains Agr. Counc. Leafy Spurge Symp. Silver Creek, Colo. p.40.

Bottoms, R.M., T.D. Whitson, and D.W. Koch. 1996. Chemical and biological control techniques for Russian knapweed. Proc. Western Soc. Weed Sci. 49:56-60.

Callihan, R.H. and J.O. Evans. 1991. Weed dynamics on rangeland. p. 55-61 In: Noxious Range Weeds. L.F. James, J.O. Evans, M.H. Ralphs, and R.D. Child, (eds.), Westview Press, Boulder, Colo.

Christianson, K., R.G. Lym, and C.G. Messersmith. 1994. Herbicides and grass competition for leafy spurge control. Proc. Great Plains Agr. Counc Leafy Spurge Symp. Bozeman, Mont. p. 8.

Dall'Armellina, A.A. and R.L. Zimdahl. 1988. Effect of light on growth and development of field bindweed (Convolvulus arvensis) and Russian knapweed Centaurea repens). Weed Sci. 36:779-783.

Ferrell, M.A., T.D. Whitson, D. Koch, R. Bottoms, and A.E. Gale. 1995. Integrated control of leafy spurge (Euphorbia esula) and Russian knapweed (Centaurea repens) with perennial grass species. Brighton Crop Protection Conf.-Weeds 3:931-936.

Ferrell, M.A., T.D. Whitson, D.W. Koch, and A.E. Gale. 1992. Integrated control of leafy spurge (Euphorbia esula) with 'Bozoisky' Russian wildrye (Psathyrostachys juncea) and 'Luna' pubescent wheatgrass (Agropyron intermedium var. trichophorum). Proc. Great Plains Agr. Counc. Leafy Spurge Symp., Lincoln, Neb. p. 4-29-4-33.

Fletcher, R.A. and A.J. Renney. 1963. A growth inhibitor found in Centaurea spp. Can. J. Plant Sci. 43:475-481.

Levy, E.B. and E.A. Madden. 1933. The point method of pasture analysis. New Zealand J. Agr. 46:267-279.

Maddox, D.M., A. Mayfield, and N.H. Poritz. 1985. Distribution of yellow starthistle (Centaurea solstitialis) and Russian knapweed (Centaurea repens). Weed Sci. 33:315-327.

Muir, A.D. and W. Majak. 1983. Allelopathic potential of diffuse knapweed (Centaurea diffusa) extracts. Can. J. Plant Sci. 63:989-996.

Stevens, K.L. and G.B. Merrill. 1985. Sesquiterpene lactones and allelochemi- cals from Centaurea species. p. 83-98 In; A.C. Thompson, (ed.), The chemistry of allelopathy: Biochemical interactions among plants. Amer. Chem. Soc., Washington, D.C

Sulima, A.G. 1968. Agronomical methods of controlling Russian knapweed [in Russian, English summary]. Zashch. Rast. 13:49-50.

Watson, A.K. 1980. The biology of Canadian weeds. 43. Acroptilon (Centaurea) repens (L.) DC. Can. J. Plant Sci. 60:993-1004.

Watson, A.K. and A.J. Renney. 1974. The biology of Canadian weeds. 6. Centaurea diffusa and C. maculosa. Can. J. Plant Sci. 54:687-701.

Whitson, T.D., D.W. Koch, A.E. Gale, and M.E. Ferrell. 1989. The control of leafy spurge (Euphorbia esula L.) by the integration of herbicides and perennial grasses. Univ. of Wyo. Rangeland Res. and Ext. Demonstrations, Coop. Ext. Service, Agr. Exp. Sta., College of Ag. P. 42-47.

Whitson, T.D., J.P. Buk, D.W. Koch, and R.J. Swearingen. 1993. A comparison of four perennial grasses established in spring on their ability to establish in stands of Russian knapweed. Res. Prog. Rep. Western Soc. Weed Sci. p. I-34-I-36.

Young, S., W.W. Brown, and B. Klinger. 1970. Nigropallidal encephalomalacia in horses fed Russian knapweed (Centaurea repens L.). Amer. J. Vet. Res. 31:1393-1404. 